\title{
Development of a new real-time quantitative PCR assay for the detection of Staphylococcus aureus genotype B in cow milk, targeting the new gene adlb
}

\author{
C. Sartori, ${ }^{\star} †$ R. Boss, ${ }^{*} \ddagger$ I. Ivanovic, ${ }^{*}$ and H. U. Graber ${ }^{* 1}$ \\ *Agroscope, Food Microbial Systems, Group Microbiological Safety of Foods of Animal Origin, 3003 Berne, Switzerland \\ †Animal Physiology Group, ETH Zurich, Institute of Agricultural Sciences (IAS), 8092 Zurich, Switzerland \\ ‡Federal Food Safety and Veterinary Office, 3003 Berne, Switzerland
}

\begin{abstract}
The specific and reliable diagnosis of mastitis pathogens is essential for successful sanitation programs. The aim of the present study was to develop and evaluate a new real-time quantitative PCR (qPCR) assay for the very sensitive and specific detection of Staphylococcus aureus genotype B in cow milk samples. This mastitis pathogen is contagious and particularly prevalent in Switzerland and other central European countries. The new test is based on a rapid preparation of bacteria, followed by DNA isolation and $\mathrm{qPCR}$ for a unique target gene coding for the adhesion-like bovine protein (adlb). The inclusivity of the new target gene was $97 \%$ and the exclusivity $98 \%$, meaning that other genotypes and bacterial species could be excluded with high reliability. The limit of detection of the new assay was 235 staphylococcal cell equivalents/mL of culture. The new test shows high intra- and interassay repeatability. Results are available within $2 \mathrm{~d}$ after sampling, allowing farmers and veterinarians to apply sanitation measures immediately. Based on the results of a preliminary field study, the diagnostic sensitivity and specificity of the new qPCR assay are 99 and $100 \%$, respectively. The new analytical procedure is straightforward and can be applied for routine diagnostics.
\end{abstract}

Key words: mastitis, milk, Staphylococcus aureus, diagnostics, real-time quantitative PCR

\section{INTRODUCTION}

Staphylococcus aureus is one of the most prevalent pathogens causing IMI in cattle, responsible for substantial milk, quality, and economic loss in dairy farming worldwide (Barkema et al., 2009; Halasa et al., 2009; Hogeveen et al., 2011; Fluit, 2012). This pathogen typically causes subclinical, chronic mastitis (Sears

Received March 2, 2017.

Accepted June 2, 2017.

${ }^{1}$ Corresponding author: hansulrich.graber@agroscope.admin.ch and McCarthy, 2003; Petersson-Wolfe et al., 2010), and previous studies confirmed that various genotypes of Staph. aureus exist, differing in their infection behavior (Sommerhäuser et al., 2003; Fournier et al., 2008; Graber et al., 2009). Important pathogenicity factors, making the therapy and elimination of Staph. aureus much more difficult, include the ability of the bacterium to persist intracellularly within mammary epithelial cells and neutrophils (Löffler et al., 2014; Peton and Le Loir, 2014), to evade the innate immune response of infected hosts (Zecconi and Scali, 2013), and to build microabscesses (Fox et al., 2001). Additionally, Staph. aureus can build biofilms, which are clusters of bacteria embedded in polysaccharides, proteins, and extracellular DNA (Fluit, 2012). Biofilm-forming bacteria are more resistant against the host immune response and antibiotic therapy (Fluit 2012; Peton and Le Loir, 2014). Finally, Staph. aureus represents a potential public health threat because of its ability to produce enterotoxins (Peton and Le Loir, 2014). Enterotoxins can lead to staphylococcal food poisoning, characterized by abdominal pain, vomiting, and diarrhea appearing 0.5 to $8 \mathrm{~h}$ after ingestion of contaminated food (Zhang and Stewart, 2001).

Control and eradication (sanitation) programs represent the most promising strategy for farmers to prevent contagious mastitis (Petersson-Wolfe et al., 2010). Implementation of such programs is reasonable because of the often unsatisfactory cure rate, which can be achieved with antibiotic therapy against Staph. aureus in single cows (Sol et al., 1997; Sol et al., 2000; Gruet et al., 2001; Sears and McCarthy, 2003; Barkema et al., 2006). Further reasons are the inappropriate use of antibiotics for mastitis therapy (Pyörälä, 2009), as well as the limited efficacy of vaccination against Staph. aureus IMI (Peton and Le Loir, 2014; Schukken et al., 2014; Landin et al., 2015).

The analytical method to detect Staph. aureus in mastitis milk samples is fundamental. Classical, phenotypical bacteriology currently represents the gold-standard for routine analysis of clinical milk samples (Koskinen 
et al., 2010), probably because most diagnostics laboratories offer this kind of analysis and because costs are relatively low compared with more advanced molecular biology methods. Bacteriological culturing for Staph. aureus has some important limitations, such as the time required for analysis, the objective interpretation of results, and the nonsatisfactory analytical sensitivity and specificity (Studer et al., 2008; Koskinen et al., 2009; Hogeveen et al., 2011). Furthermore, as bacteriology is a phenotypical method, it does not differ between genotypes. Finally, 3 consecutive analyses of aseptically collected milk samples are required to reach a high diagnostic sensitivity (Sears et al., 1990; Studer et al., 2008). Therefore, the minimum time required to clarify the status of an animal is about 1 mo, considering time intervals of 2 to 3 wk between samplings (Kirchhofer et al., 2011). This extended time interval represents an elevated risk for new infections of herdmates.

For Staph. aureus, the possibility to specifically discriminate between the different genotypes is crucial, because they are characterized by different epidemiological, clinical, and pathogenicity properties (Fournier et al., 2008), and only genotype B (GTB) exhibits a contagious model of transmission (Fournier et al., 2008; Cremonesi et al., 2015; van den Borne et al., 2017). Staphylococcus aureus GTB is characterized by high prevalence, both at the quarter and at the cow level, whereas genotype C (GTC) and other genotypes (GTOG) are responsible for single-quarter, sporadic infections of individual cows (Fournier et al., 2008; Graber et al., 2009). According to Fournier et al. (2008), Staph. aureus GTB shows a typical virulence gene pattern, including the presence of the enterotoxin genes sea, sed, and sej, and a SNP within the leukotoxin E (lukE) gene called lukEB. This specific pattern provides scope for the differentiation of GTB from other genotypes. Finally, GTB shows an increased pathogenicity compared with GTC and GTOG, which is reflected in higher SCC in the milk of infected cows (Fournier et al., 2008).

As previously described (Cosandey et al., 2016), about $10 \%$ of the Swiss dairy herds are positive for Staph. aureus GTB. This estimation was based on the analysis of 223 bulk tank milk samples stratified among the number of dairy herds per canton; the same analyses further showed local differences among the herd prevalence for Staph. aureus GTB (Cosandey et al., 2016). As described by Voelk et al. (2014) and van den Borne et al. (2017), in mountainous regions of Switzerland cows from several different herds are typically brought together during the summer months on communal operations (alps), where they are pastured and milked together, sharing the milking equipment and housing facilities. The study by Voelk et al. (2014), investigating the prevalence of Staph. aureus GTB on alps, revealed that the within-herd GTB prevalence reached up to $72 \%$ of the cows at the end of the summer season. The milk produced on alps is mostly made into raw milk cheese, and the study by Hummerjohann et al. (2014) showed that Staph. aureus GTB is the most abundant subtype of Staph. aureus isolated from these cheeses. The successful transfer of Staph. aureus GTB from the bovine udder to the cheese production chain was further observed in a recent study conducted in Austria by Kuemmel et al. (2016), confirming the importance of this udder pathogen for food safety. According to Heiniger et al. (2014), Staph. aureus GTB is responsible for about $60 \%$ of the total mastitis cost in Switzerland, corresponding to approximately 80 million Swiss Francs per year.

Considering the notable prevalence of Staph. aureus GTB in Switzerland, as well as its implications for udder health, food safety, and its economic impact on Swiss agriculture, the aim of the present study was to develop and evaluate a simplified real-time quantitative (q)PCR assay for the very specific and sensitive detection of Staph. aureus GTB in bovine milk samples, targeting the new, single copy gene $a d l b$, which codes for the adhesion-like bovine protein. The new test represents a very solid diagnostic tool to routinely monitor the Staph. aureus GTB status of dairy herds, as well as to support the decision-making process during sanitation programs for this contagious udder pathogen.

\section{MATERIALS AND METHODS}

The development and validation of the new qPCR assay for Staph. aureus GTB in bovine milk samples are based on the guidelines proposed by the World Organisation for Animal Health (OIE, 2016a,b,c). All primers and probes used for the development of the new qPCR assay (including those for standard PCR and for sequencing of the target gene) were designed using the Oligo 6.51 software (Molecular Biology Insights Inc., Cascade, CO), synthetized by Microsynth (Balgach, Switzerland) or Thermo Fisher Scientific (Darmstadt, Germany), and are listed in Table 1.

\section{Selection of Target Gene, Primers, and Probe for $\mathrm{QPCR}$}

To find a unique target gene specific for Staph. aureus GTB, 2 corresponding strains (M5512B, M6020B) isolated from subclinical bovine IMI were sequenced by next-generation sequencing using 454 technology (Roche, Basel, Switzerland). This procedure including the assembly of the contigs was performed by Microsynth. The obtained contigs were aligned to Staph. au- 
reus NCTC8325 using Mauve 2.3.1. software (Darling et al., 2004) and joined to construct a full chromosomal genome. Using Clone Manager 9.1 software (Scientific \& Educational Software, Denver, CO) and multiple sequence alignments, the GTB genomes were compared with complete Staph. aureus genomes present in the Nucleotide database (National Center for Biotechnology Information, Bethesda, MD), including N315, MW2, USA300, MSSA176, MRSA252 (all human strains), RF122 (bovine), ED133 (sheep), and ED98 (poultry). Based on these analyses, a GTB-specific target gene was detected. Appropriate primers and a hydrolysis probe were then designed (Table 1) using Oligo 6.51 software (Molecular Biology Insights). The probe contained a confidential minor groove binder and was labeled with 6-carboxyfluorescein (FAM) at the $5^{\prime}$ end and with a confidential quencher at the $3^{\prime}$ end (Thermo Fisher Scientific). The novel target gene was further characterized in silico using Interpro (EMBLEBI, Hinxton, UK), Uniprot (The UniProt Consortium,
Geneva, Switzerland), and Clone Manager 9.1 Software (Scientific \& Educational Software).

\section{Standard PCR and DNA Sequencing of the Target Gene}

Sequencing was carried out to look for conserved regions within the target gene used later on to develop the new qPCR assay. The aim was to reduce the risk of false-negative and false-positive results for the definite assay. For this purpose, 25 Staph. aureus GTB strains from our strain collection were randomly selected and cultured on blood agar (BA) medium (Biomérieux Suisse s.a., Geneva, Switzerland) at $37^{\circ} \mathrm{C}$ overnight. The DNA was extracted by boiling (see below). For the amplification of the adlb gene, standard PCR was performed in a total volume of $25 \mu \mathrm{L}$ containing $1 \times$ HotStarTaq Master Mix (Qiagen AG, Hombrechtikon, Switzerland), $300 \mathrm{n} M$ both primers (Gadlb-S, GadlbAS; Table 1), and $2.5 \mu \mathrm{L}$ of the 1:100 diluted DNA.

Table 1. Overview on the different types of PCR performed for the development of the new real-time quantitative PCR (qPCR) assay for Staphylococcus aureus genotype B (GTB), including targets, primers, and probes

\begin{tabular}{|c|c|c|c|}
\hline Target $^{1}$ & $\begin{array}{l}\text { Amplicon } \\
\text { size (bp) }\end{array}$ & $\begin{array}{l}\text { Primer/probe } \\
\text { name }\end{array}$ & Primers/probe sequence $\left(5^{\prime}-3^{\prime}\right)$ \\
\hline \multicolumn{4}{|l|}{ Standard PCR } \\
\hline RS-PCR & Various & G1 & GAA GTC GTA ACA AGG ${ }^{2}$ \\
\hline \multirow[t]{2}{*}{$a d l b$} & \multirow[t]{2}{*}{645} & Gadlb-S & GTG ATG GAG GTA CTC TAA ATA $\mathrm{CA}^{3}$ \\
\hline & & Gadlb-AS & CCC AAA TAT TAT CTG CAT CT ${ }^{3}$ \\
\hline \multirow{2}{*}{$\begin{array}{l}\text { Real-time qPCR } \\
\text { lukEB }\end{array}$} & \multirow{2}{*}{178} & & \\
\hline & & QlukE-P & $\mathrm{TG}[\mathrm{A}] \mathrm{GT}[\mathrm{A}] \mathrm{A}[\mathrm{C}] \mathrm{G}[\mathrm{C}] \mathrm{C}[\mathrm{C}] \mathrm{C}[\mathrm{A}] \mathrm{T}^{4,5}$ \\
\hline \multirow[t]{3}{*}{ sea } & \multirow[t]{3}{*}{168} & QseaM-S & GCC GAT CAA TTT ATG GCT AGA C ${ }^{4}$ \\
\hline & & QseaM-AS & CTC TGA ACC TTC CCA TCA AAA AC ${ }^{4}$ \\
\hline & & QseaM-P & ACA GTA CCT TTG GAA ACG ${ }^{4,6}$ \\
\hline \multirow[t]{3}{*}{ sed } & \multirow[t]{3}{*}{93} & QsedM-S & TTA CCG TAC AAG AAT TAG ATG CAC AAG ${ }^{4}$ \\
\hline & & QsedM-AS & GCT GTA TTT TTC CTC CGA GAG TAT CA ${ }^{4}$ \\
\hline & & QsedM-P & AAG GCG CTA TTT GC ${ }^{4,6}$ \\
\hline CDVN & 130 & QCDVN-P & CTC ATC TGC CTC AGA ATC CAA ACT TGC TC ${ }^{7,8}$ \\
\hline \multirow[t]{2}{*}{$\begin{array}{l}\text { Melting curve PCR } \\
\text { nuc }\end{array}$} & \multirow{2}{*}{664} & Nuc-S & CTG GCA TAT GTA TGG CAA TTG TT ${ }^{7}$ \\
\hline & & Nuc-AS & TAT TGA CCT GAA TCA GCG TTG TCT ${ }^{7}$ \\
\hline
\end{tabular}

${ }^{1} \mathrm{RS}-\mathrm{PCR}=16 \mathrm{~S}-23 \mathrm{~S}$ rRNA intergenic spacer region PCR; adlb = gene coding for the adhesion-like bovine protein; lukEB = SNP within the lukE gene (coding for leucotoxin E); sea, sed = genes of Staphylococcus aureus coding for the enterotoxins A and D; CDVN = N gene of the canine distemper virus; $n u c=$ thermonuclease gene; $\mathrm{S}=$ sense primer; $\mathrm{AS}=$ antisense primer; $\mathrm{P}=$ probe.

${ }^{2}$ Reference: Jensen et al. (1993).

${ }^{3}$ Reference: this paper.

${ }^{4}$ Reference: Boss et al. (2011).

${ }^{5}$ Real-time quantitative PCR probe containing locked nucleic acids (in brackets) and labeled with 6-carboxyfluorescein (FAM) at the 5' end and with black hole quencher-1 at the 3 ' end.

${ }^{6}$ Minor groove binder (MGB) qPCR probe labeled with FAM at the $5^{\prime}$ end and with a confidential nonfluorescent quencher at the $3^{\prime}$ end.

${ }^{7}$ Reference: Graber et al. (2007).

${ }^{8}$ Real-time quantitative PCR probe labeled with FAM at the $5^{\prime}$ end and with 6-carboxytetramethylrhodamin (TAMRA) at the 3 ' end. 
The Gadlb-S started at nucleotide 1,724, and GadlbAS ended at nucleotide 2,369; the resulting amplicon consists of $645 \mathrm{bp}$. The DNA amplification was carried out by a Biometra cycler system (Biometra $\mathrm{GmbH}$, Göttingen, Germany). The cycling conditions of the standard PCR were an initial denaturation step $\left(95^{\circ} \mathrm{C}\right.$, 10 min), 35 cycles comprising denaturation at $94^{\circ} \mathrm{C}$, annealing at $54^{\circ} \mathrm{C}$ and elongation at $72^{\circ} \mathrm{C}$, each for 1 min, followed by a final elongation step at $72^{\circ} \mathrm{C}$ for 10 min and cooling to $4^{\circ} \mathrm{C}$. The PCR products were stored at $-25^{\circ} \mathrm{C}$ until further processing and then analyzed on the miniaturized electrophoresis system Agilent DNA 7500 Chip (Agilent Technologies, Basel, Switzerland) to test for PCR amplification and the purity of the PCR product. Finally, PCR products were sent to Microsynth for purification and sequencing of the $a d l b$ gene; Gadlb-S was used as sequencing primer (Table 1).

\section{Isolation of Bacterial DNA and Limit of Detection}

Two different extraction procedures were used for the isolation of DNA from bacteria, depending on the purpose of the experiment.

Short Extraction Protocol (Boiling Preparation). To determine the inclusivity and exclusivity of the new qPCR assay, a short extraction protocol was applied. Strains from our strain collection, which were conserved in skim milk were grown overnight on BA at $37^{\circ} \mathrm{C}$. One colony of each strain was picked from BA using a sterile plastic loop and inoculated in $100 \mu \mathrm{L}$ of $10 \mathrm{~m} M$ Tris $/ \mathrm{HCl}$ and $10 \mathrm{mM} \mathrm{Na} \mathrm{EDTA}_{2}(\mathrm{pH}=8.5$ ). Eppendorf tubes were incubated for $10 \mathrm{~min}$ at $95^{\circ} \mathrm{C}$ and then immediately placed on ice. A 1:100 dilution step of the DNA always preceded qPCR.

Simplified Extraction Protocol After Enrichment. The simplified extraction protocol according to Voelk et al. (2014) was used for the analysis of clinical milk samples.

Bacterial cultures were prepared by adding $500 \mu \mathrm{L}$ of milk to $4.5 \mathrm{~mL}$ of Chapman medium $[10 \mathrm{~g} / \mathrm{L}$ of casein-peptone (Merck AG, Zug, Switzerland), $1 \mathrm{~g} / \mathrm{L}$ of Lab-Lemco powder (Oxoid, Pratteln, Switzerland), 75 $\mathrm{g} / \mathrm{L}$ of $\mathrm{NaCl}$ (Merck AG), $10 \mathrm{~g} / \mathrm{L}$ of D-mannitol (SigmaAldrich Chemie GmbH, Buchs, Switzerland)] and then incubated for $18 \mathrm{~h}$ at $37^{\circ} \mathrm{C}$ under constant shaking. After this bacterial enrichment step, DNA was extracted using the mericon DNA Bacteria Plus Kit (Qiagen $\mathrm{AG})$, according to the instructions of the manufacturer (https://www.qiagen.com/us/resources/resourcedetail ?id=8a513dcc-dfc3-4101-bdb3-3f846b68ba87\&lang= en). In brief, $1 \mathrm{~mL}$ of bacterial culture was added to $650 \mu \mathrm{L}$ of extraction mix, which contained $150 \mu \mathrm{L}$ of Lactobacillus casei $\left(10^{10} \mathrm{cfu} / \mathrm{mL}\right), 300 \mu \mathrm{L}$ of Triton
X-100 (2\%; Sigma-Aldrich Chemie GmbH), and $200 \mu \mathrm{L}$ of Tris $/ \mathrm{HCl}(100 \mathrm{~m} M, \mathrm{pH}=7.8)$. After centrifugation $\left(18,000 \times g\right.$ for $5 \mathrm{~min}$ at $\left.4^{\circ} \mathrm{C}\right)$, the supernatant was discarded using a vacuum pump. The bacterial pellet was resuspended in $400 \mu \mathrm{L}$ of Fast Lysis Buffer (Qiagen AG) and, after transfer into the Pathogen Lysis Tubes (Qiagen AG), samples were horizontally vortexed for 10 min at maximal power. After centrifugation $(13,000$ $\times g$ for 5 min at $25^{\circ} \mathrm{C}$ ), $100 \mu \mathrm{L}$ of the supernatant was transferred into a new tube and used as template DNA for qPCR analysis.

The simplified extraction protocol was also used to determine the limit of detection of the new qPCR assay after enrichment of the milk samples. Starting from a liquid, log-phase culture of Staph. aureus GTB containing $2.35 \times 10^{9}$ staphylococcal cell equivalents $(\mathbf{S C E})$ per $\mathrm{mL}\left(\mathrm{V}^{0}\right)$, a $1: 10$ dilution series $\left(\mathrm{V}^{-1}\right.$ to $\left.\mathrm{V}^{-10}\right)$ was produced starting from $\mathrm{V}^{0}$ in Chapman medium. To simulate the enrichment of real milk samples collected in the field, $500 \mu \mathrm{L}$ of each dilution $\left(\mathrm{V}^{-1}\right.$ to $\left.\mathrm{V}^{-10}\right)$ were incubated with $500 \mu \mathrm{L}$ of cow raw milk (bacteriologically sterile) and $4 \mathrm{~mL}$ of Chapman medium (18 h, $37^{\circ} \mathrm{C}$, under constant shaking). Finally, DNA was isolated following the procedure described above.

\section{qPCR for adlb}

Primers for $\mathrm{qPCR}$ are reported in Table 1 . The sense primer (QadlbM-S) binds at position 2070 of the $a d l b$ gene and the antisense primer (QadlbM-AS) ends amplification at position 2165. The amplified region consists of $95 \mathrm{bp}$. The probe for $a d l b$ was minor groove binder-labeled with 6-carboxyfluorescein at the $5^{\prime}$ end (reporter) and a confidential dark quencher at the $3^{\prime}$ end (Boss et al., 2011) and was synthesized by Thermo Fischer Scientific. The qPCR reactions were run in a total volume of $25 \mu \mathrm{L}$, containing $1 \times$ Roche LightCycler 480 Probes Master (Roche), $600 \mathrm{n} M$ sense and antisense primer, $100 \mathrm{n} M$ probe (QadlbM-P), and $3.5 \mu \mathrm{L}$ of the DNA template. The DNA was isolated from the bacteria using 1 of the 2 isolation methods, as described previously. Amplification of the DNA was performed in a Rotor-Gene 6000 real-time thermal cycler (Corbett Life Science, Mortlake, Australia) under the following cycling conditions: after an initial denaturation step $\left(95^{\circ} \mathrm{C}, 10 \mathrm{~min}\right), 45$ cycles were run, including denaturation at $95^{\circ} \mathrm{C}$ for $15 \mathrm{~s}$ and annealing and elongation at $60^{\circ} \mathrm{C}$ for 1 min. According to Boss et al. (2011), qPCR reactions were always run in duplicate for the target gene $a d l b$, considering as positive only those samples for which both reactions were positive. If only 1 reaction showed a positive result or the difference of the 2 cycleto-threshold $(\mathbf{C t})$ values was more than 2 cycles, qPCR 
Table 2. Bacterial strains analyzed for the determination of the inclusivity (97\%) and exclusivity (98\%) of the new real-time quantitative PCR assay for Staphylococcus aureus genotype B (percent in parentheses)

\begin{tabular}{|c|c|c|c|}
\hline \multirow[b]{2}{*}{ Bacterial strain ${ }^{1}$} & \multirow[b]{2}{*}{$\mathrm{n}$} & \multicolumn{2}{|c|}{ Presence of $a d l b^{2}$} \\
\hline & & Neg. ${ }^{3}$ & Pos. ${ }^{3}$ \\
\hline GTB & $99(100)$ & $3(3)$ & $96(97)$ \\
\hline \multicolumn{4}{|l|}{ Non-GTB } \\
\hline GTC & 24 & 24 & 0 \\
\hline GTOG & 24 & 23 & 1 \\
\hline NSA & 10 & 10 & 0 \\
\hline Streptococci & 3 & 3 & 0 \\
\hline Escherichia coli & 1 & 1 & 0 \\
\hline Total non-GTB & $62(100)$ & $61(98)$ & $1(2)$ \\
\hline
\end{tabular}

${ }^{1} \mathrm{GTB}=$ Staphylococcus aureus genotype B; $\mathrm{GTC}=$ Staph. aureus genotype C; GTOG $=$ other genotypes than GTB and GTC; NSA = non-Staph. aureus staphylococci.

${ }^{2}$ Target gene: $a d l b=$ gene coding for the adhesion-like bovine protein.

${ }^{3} \mathrm{Neg}$. = number of negative real-time quantitative PCR results; Pos. = number of positive real-time quantitative PCR results.

was repeated. For each run, a qPCR standard curve was included according to Boss et al. (2011), ranging from 10 to $10^{7}$ copies/assay.

\section{Assay Controls}

According to Graber et al. (2007) and Boss et al. (2011), various controls were included to monitor the whole procedure. To evaluate the preparation of Staph. aureus GTB from milk (enrichment and DNA extraction controls), 1 sample of raw milk negative for Staph. aureus and 1 raw milk sample spiked with approximately $10^{5} \mathrm{cfu} / \mathrm{mL}$ of Staph. aureus GTB were always co-processed with the test samples (Graber et al., 2007; Boss et al., 2011). If the negative raw milk sample showed amplification or if the spiked sample was not within the adequate range $( \pm 1$ cycle of the expected Ct-value), all test samples of the affected series were prepared again (Boss et al., 2011). This was never necessary during our experiments.

For each qPCR run, 1 no-template control and 1 Staph. aureus GTB-positive control were included. If the results were positive for no-template control or negative for positive control, the run was repeated. To check for qPCR inhibitors present in the DNA, samples were always analyzed by an additional qPCR containing amplicons of the $\mathrm{N}$ gene of the canine distemper virus ( $10^{3}$ copies/assay) as an internal control. Negative qPCR results for the $a d l b$ target sequence required a positive $\mathrm{qPCR}$ result for the $\mathrm{N}$ gene of the canine distemper virus to exclude inhibitors (Graber et al., 2007; Boss et al., 2011).

\section{Bacterial Strains}

To evaluate the inclusivity and exclusivity of the new qPCR assay, a selection of udder pathogens with known identity from our strain collection were tested for the presence of the target gene adlb (Table 2). All bacterial strains used for this purpose were originally isolated from aseptically collected bovine milk samples and then stored in skim milk at $-25^{\circ} \mathrm{C}$. For isolation of the DNA, bacteria were recultured on BA and incubated overnight at $37^{\circ} \mathrm{C}$.

A total of 147 Staph. aureus strains were included in the study. All strains were obtained from previous studies (Graber et al., 2007; Fournier et al., 2008; Cosandey et al., 2016) and were randomly selected. They were isolated from bovine milk samples with spontaneous Staph. aureus IMI and were epidemiologically unrelated, meaning that they originated from different farms. Out of them, 99 strains were GTB, 24 were GTC, and 24 were GTOG; all resulted positive for the Staph. aureus-specific nuc gene (Brakstad et al., 1992; Graber et al., 2007).

A selection of 10 non-Staph. aureus staphylococci (NSA) were obtained from the DSMZ (Deutsche Sammlung von Mikroorganismen und Zellkulturen GmbH, Braunschwieg, Germany), including Staphylococcus saprophyticus ssp. saprophyticus (DSM 20229), Staphylococcus epidermidis (DSM 20044), Staphylococcus haemolyticus (DSM 20263), Staphylococcus xylosus (DSM 20266), Staphylococcus warneri (DSM 20316), Staphylococcus intermedius (DSM 20373), Staphylococcus chromogenes (DSM 20454), Staphylococcus hyicus (DSM 20459), Staphylococcus caprae (DSM 20608), and Staphylococcus simulans (DSM 20322). Furthermore, 3 streptococcal strains (Streptococcus uberis, Streptococcus agalactiae, and Streptococcus dysgalactiae) and 1 Escherichia coli strain were included. These strains were isolated from quarters with spontaneous IMI during a previous study by Wyder et al. (2011). The 3 streptococcal strains were identified by PCR, as de- 
scribed by Raemy et al. (2013), as well as the E. coli strain, according to Riffon et al. (2001).

\section{Spiking Experiments}

A possible negative influence of foreign (NSA) DNA on the amplification of the adlb gene was investigated by analyzing Staph. aureus GTB DNA samples $\left(10^{4}\right.$ to $10^{7} \mathrm{SCE} /$ assay) after addition of DNA extracts from 3 different NSA (Staph. chromogenes, Staphylococcus sciuri, and Staph. xylosus, at concentrations of $10^{2}$ to $10^{7} \mathrm{SCE} /$ assay) into the master mix used for $\mathrm{qPCR}$. The DNA of all strains used for this experiment were isolated using the boiling prep protocol, followed by DNA purification using the High Pure PCR Template Preparation Kit (Roche). All combinations of Staph. aureus GTB and each NSA were separately analyzed by $\mathrm{qPCR}$.

\section{Diagnostic Sensitivity and Specificity (Clinical Milk Samples)}

Milk samples analyzed to determine the diagnostic sensitivity and specificity of the new qPCR assay originated from 20 GTB-positive dairy herds, which participated in a longitudinal field study aiming to eradicate Staph. aureus GTB from the milking herd (C. Sartori, unpublished data). The within-herd prevalence for Staph. aureus GTB in those herds was between 5 and $57 \%$, with a median of $20 \%$ (GTB-positive cows per herd). After cow preparation for milking by the farming personnel (including forestripping and teat cleaning), samples were collected either under clean conditions (composite foremilk samples of each cow) or under aseptic conditions (single-quarter foremilk samples, which were then pooled in the laboratory to form a composite milk sample of each cow).

During the first sampling of all herds (median herd size $=25$ cows, with a minimum of 11 and a maximum of 108 cows/herd) participating in the sanitation study, a total of about 500 single-cow milk samples was collected. Of those, 241 milk samples were randomly selected (including both GTB-positive and -negative samples in approximately equal amounts) and analyzed using 2 different qPCR assays: (1) the new qPCR assay based on the detection of the unique target gene adlb was compared with (2) the established qPCR assay by Boss et al. (2011), which was used as a reference and relies on the detection of the 3 targets lukEB, sea, and sed. A positive result for Staph. aureus GTB is given when the targets lukEB and sea or sed (or both) are positive (Boss et al., 2011), or when the unique target gene $a d l b$ is positive (new qPCR assay). According to Syring et al. (2012), a reaction was considered positive if the amplification of the targets lukEB, sea, and sed resulted in a value of $1.21 \times 10^{4}$ copies/assay. For the new qPCR assay, a reaction was considered positive if the amplification of the unique target gene $a d l b$ resulted in a value of $9.25 \times 10^{4}$ copies/assay, corresponding to a $\mathrm{Ct}$ value of 21.8. The cut-off $\mathrm{Ct}$ value for a positive qPCR result was calculated (according to Bustin et al., 2009; Caraguel et al., 2011) by adding 3 times the standard deviation to the mean value of all positive and always replicable results (dilution $\mathrm{V}^{-4}$ ) obtained during the repeatability experiments.

In the case of a discrepancy in the final result (samples being positive with only 1 of the 2 qPCR assays), samples were further analyzed by $16 \mathrm{~S}-23 \mathrm{~S}$ rRNA intergenic spacer region PCR (RS-PCR; Fournier et al., 2008). For this purpose, the originally collected milk samples were thawed and $20 \mu \mathrm{L}$ of each sample were plated on BA and incubated overnight at $37^{\circ} \mathrm{C}$. For samples showing no growth after incubation, an enrichment step was performed (1:10 dilution of the milk sample in Chapman medium, in a total volume of 5 $\mathrm{mL}$ ) and the enriched samples were then plated on BA and processed identically to the unenriched samples.

From each BA plate, 5 colonies were randomly selected and DNA was isolated using the boiling preparation method. For the definitive identification of Staph. aureus, DNA was diluted 1:100 and melting curve PCR was performed for each sample for the target gene nuc.

Each nuc-positive sample was finally analyzed by RSPCR (Fournier et al., 2008), which is the gold-standard method for genotyping. This includes, in brief, the amplification of the 16S-23S rRNA intergenic spacer region by PCR (Fournier et al., 2008), followed by the analysis of the PCR products using the miniaturized electrophoresis system Agilent DNA 7500 Chip (Agilent Technologies). This system separates amplicons of DNA according to their size, which results in a plot of correspondent peaks (electropherogramm) that can be monitored on a personal computer, evaluated, and translated in a pseudo-gel by a particular software (Agilent Technologies, according to Fournier et al., 2008). The interpretation of the resulting electropherogramms was performed using the in-house developed Mahal program (Syring et al., 2012).

\section{Repeatability}

Interassay Variability. To determine the interassay variability of the new qPCR assay, serial 1:10 dilutions of Staph. aureus GTB were completely analyzed 20 times. Five complete analysis rounds of the same dilution series were performed per working day, on each of 4 consecutive days. All samples were independently processed following all steps of the analytical procedure 
(bacterial enrichment, DNA extraction, and qPCR analysis). Dilution series $\left(\mathrm{V}^{-1}\right.$ to $\left.\mathrm{V}^{-10}\right)$ were produced starting from a liquid, log-phase culture $\left(\mathrm{V}^{0}\right)$ of Staph. aureus GTB. For bacterial enrichment, $500 \mu \mathrm{L}$ of each dilution and $500 \mu \mathrm{L}$ of cow raw milk (bacteriologically sterile) were added to $4 \mathrm{~mL}$ of Chapman medium and incubated for $18 \mathrm{~h}$ at $37^{\circ} \mathrm{C}$ under constant shaking. Thereafter, DNA was isolated using the simplified extraction protocol and, finally, all samples of each dilution series were analyzed by qPCR for the target gene adlb on 20 different runs.

Intra-Assay Variability. To determine the intraassay variability of the new qPCR assay, a 1:10 dilution series $\left(\mathrm{V}^{-1}\right.$ to $\left.\mathrm{V}^{-6}\right)$ of Staph. aureus GTB was prepared and analyzed as described for the interassay experiment. After bacterial enrichment, the DNA was independently isolated 5 times from each of the 6 dilutions using the same extraction mix and the simplified protocol. Finally, each sample was analyzed for $a d l b$ on the same qPCR run, using a new qPCR master mix for each of the 5 subseries $\left(\mathrm{V}^{-1}\right.$ to $\left.\mathrm{V}^{-6}\right)$.

\section{Statistical Analysis}

Data were expressed as absolute or relative frequencies (\%). Inclusivity, exclusivity, as well as diagnostic sensitivity and specificity were calculated in the standard manner (OIE, 2016b). A 2-factor ANOVA was performed to compute the overall standard deviation of the intra-assay variability expressed in $\mathrm{Ct}$ values. The 2 independent factors were sample dilution and qPCR master mix. As a post hoc test, the Scheffé test was applied. For all the statistical analyses, the Systat 13.1 software package (Systat Software, San Jose, CA) was used. Values of $P<0.05$ were considered to be significant.

\section{RESULTS}

\section{Characterization of the Target Gene}

The target gene of the GTB strains M5512B and M6020B were both 3,798 bp long, resulting in a protein of 1,265 AA. It includes an N-terminal gram-positive signal peptide at AA 17 to 54 and a C-terminal grampositive Leu-Pro-any-Thr-Gly cell wall anchor at AA 1,219 to 1,257. Furthermore, the protein harbors 3 G5 domains (AA 842-921, AA 960-1,042, AA 1,088-1,170); in between, $2 \mathrm{E}$ domains are located (AA 914-961, AA 1,042-1,089). The G5 domains are involved in bacterial adhesion so that both the protein and gene were named adhesion-like bovine protein ( $a d l b)$.

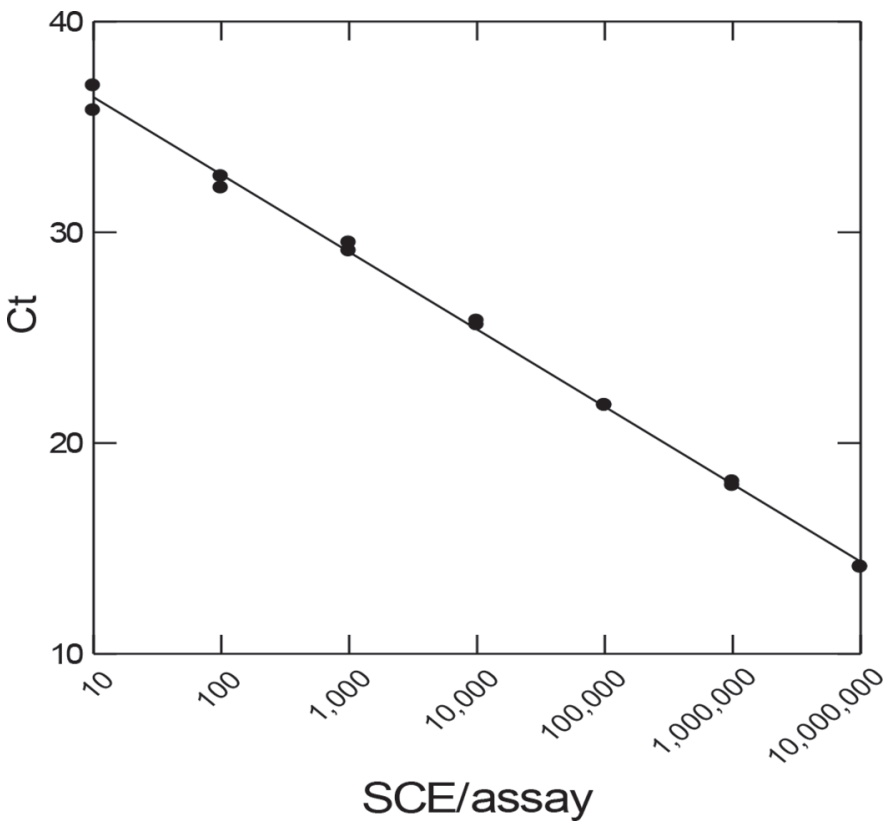

Figure 1. Standard curve obtained for real-time quantitative PCR (qPCR) using the $a d l b$ gene as the target. Serial dilutions of a purified $a d l b$ gene amplicon were made starting at $10^{7}$ staphylococcal cell equivalents (SCE)/assay and ending at $10 \mathrm{SCE} /$ assay. The dilutions were amplified by the standard adlb gene qPCR protocol, and the corresponding cycles to reach a defined threshold $(\mathrm{Ct})$ were determined. The SCE/assay values $\left(\log _{10}\right.$ scale) were then plotted against the obtained $\mathrm{Ct}$ values. The observed coefficient of correlation was $\mathrm{R}=$ -0.999 . The equation describing the standard curve was $\mathrm{Ct}=-3.6734$ $\times \log _{10}(\mathrm{SCE} /$ assay $)+40.08$.

\section{qPCR Assay Performance}

Using serial dilutions of a purified adlb gene amplicon, the assay was shown to give linear results between 10 and $10^{7} \mathrm{SCE} /$ assay. As a qPCR standard, therefore, we chose concentrations between 10 and $10^{7} \mathrm{SCE}$ per run. For this range, the coefficient of correlation was -0.999 (Figure 1). The amplification efficiency was 0.91 , as measured on the gradient.

\section{Analytical Specificity}

Inclusivity. Out of the 99 Staph. aureus GTB strains analyzed to determine the inclusivity of the new qPCR assay, 96 strains resulted positive for $a d l b$, whereas 3 strains were negative, resulting in an inclusivity of $97 \%$ $(95 \% \mathrm{CI}= \pm 2)$ for the new target gene (Table 2).

Exclusivity. Out of the 62 strains other than Staph. aureus GTB analyzed to determine the exclusivity of the new qPCR assay, all the Staph. aureus GTC strains, as well as the streptococci, the E. coli, and all the NSA strains were found to be negative for $a d l b$. Only 1 GTOG strain was positive for $a d l b$, resulting in 
an exclusivity of $98 \%(95 \% \mathrm{CI}= \pm 2)$ for the new target gene adlb (Table 2).

\section{Spiking Experiments}

No systematic shift of the adlb amplification signals (Ct values) was observed for any of the 6 amounts of DNA of each NSA compared with those of the nonspiked samples, which represented the reference value. The range of variation between the $\mathrm{Ct}$ values of spiked and nonspiked samples was 0.23 cycles for Staph. chromogenes, 0.45 cycles for Staph. sciuri, and 0.58 cycles for Staph. xylosus.

\section{Analytical Sensitivity}

The limit of detection of the novel assay was evaluated by analyzing serial 1:10 dilutions of a Staph. aureus GTB culture after enrichment, according to the standard procedure as used for inferring the interassay variability (see below). Out of 5 repetitive dilution experiments, 3 gave a positive qPCR result for $\mathrm{V}^{-7}$, which

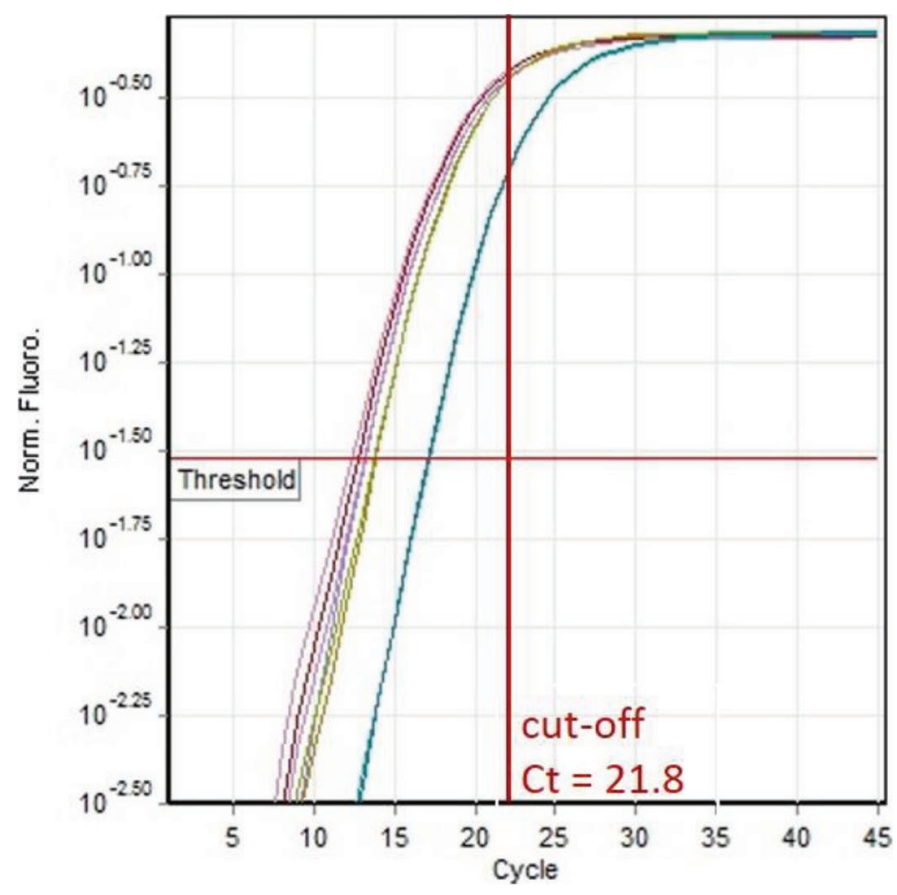

Figure 2. Positive real-time quantitative PCR ( $\mathrm{qPCR}$ ) results after milk sample enrichment and cut-off for a positive qPCR result. Samples contained $3.25 \times 10^{8}$ to $3.25 \times 10^{5}$ staphylococcal cell equivalents (SCE)/mL before enrichment and were analyzed in duplicate. The resulting cycles to reach the threshold (Ct values) showed a relatively narrow range of variation $(17.13>\mathrm{Ct}>12.33)$, independent of the bacterial concentration present in the samples before enrichment. The vertical line (at $\mathrm{Ct}=21.8$ ) represents the cut-off value for a positive $\mathrm{qPCR}$ result. Norm. Fluoro. = normalized fluorescence. corresponds to a detection limit of $2.35 \times 10^{2} \mathrm{SCE} / \mathrm{mL}$ before enrichment.

\section{Repeatability}

Interassay Variability. Replicable, positive results were obtained for all 20 analysis rounds until $\mathrm{V}^{-4}$, corresponding to $2.35 \times 10^{5} \mathrm{SCE} / \mathrm{mL}$ before enrichment. Below this concentration, repetition was no longer consistent but was observed from time to time, as was the case when inferring the limit of detection of the assay.

Intra-Assay Variability. This experiment showed replicable results for the 4 dilutions $\mathrm{V}^{-1}$ to $\mathrm{V}^{-4}$, which contained, respectively, $3.25 \times 10^{8}$ to $3.25 \times 10^{5} \mathrm{SCE} /$ $\mathrm{mL}$ before enrichment. The ANOVA, which considered the 2 independent factors dilution and qPCR master mix, resulted in an overall standard deviation of 0.59 cycles for the measured $\mathrm{Ct}$ values. The factor qPCR master mix had no influence on the $\mathrm{Ct}$ values, meaning that no shifts could be observed in the amplification curves when analyzing the same dilution using 5 different qPCR master mixes on the same qPCR run. As expected, the factor dilution had a significant effect $(P$ $<0.001$ ) on the $\mathrm{Ct}$ values, resulting in higher $\mathrm{Ct}$ values for lower dilutions (Figure 2). Mean $\mathrm{Ct}$ values were shifted 0.12 cycles for $\mathrm{V}^{-2}(P=0.976), 0.88$ for $\mathrm{V}^{-3}(P$ $=0.022)$, and 3.78 cycles for $\mathrm{V}^{-4}(P<0.001)$ compared with baseline $\mathrm{Ct}$ values for $\mathrm{V}^{-1}$.

\section{Diagnostic Sensitivity and Specificity (Clinical Milk Samples)}

A total of 241 milk samples were randomly selected and analyzed to determine the diagnostic sensitivity and specificity of the new adlb test. Both analytical methods, the reference $\mathrm{qPCR}$ assay including the targets lukEB, sea, and sed as well as the new adlb assay, delivered identical results for 225 samples (109 GTB-positive and 116 GTB-negative). A total of 16 samples showed discordant results using the 2 methods mentioned above. For 15 GTB-negative samples with the reference method, positive results were obtained by the $a d l b$ assay. In contrast, 1 sample was GTB-negative by the new adlb assay and GTB-positive by the reference method. All samples showing discordant results were further analyzed by RS-PCR (gold-standard genotyping method), whereby all of them generated a GTB-positive result. The total number of correct GTB-positive results was therefore $125(109+16)$. Of those, 124 samples were identified as GTB-positive by the adlb method, resulting in a diagnostic sensitivity of $99 \%(95 \% \mathrm{CI}= \pm 2)$. As all the GTB-negative samples were correctly identified, the diagnostic specificity for the new target gene adlb was $100 \%(95 \% \mathrm{CI}= \pm 2)$. 


\section{DISCUSSION}

The aim of the present study was the development, technical evaluation, and validation of a new diagnostic qPCR assay for the detection of Staph. aureus GTB in dairy cow milk samples. This mastitis pathogen is contagious (Graber et al., 2009; van den Borne et al., 2017) and particularly prevalent in Switzerland (Fournier et al., 2008; Graber et al., 2009) and other central European countries, including Switzerland's neighboring countries (Austria, France, Germany, and Italy) and Belgium (Cosandey et al., 2016). The new test is based on the detection of the unique target gene $a d l b$, which results in a considerable simplification compared with the GTB diagnostics currently in use (Boss et al., 2011; Syring et al., 2012), as the latter requires the parallel detection of 3 GTB-typical targets (Boss et al., 2011): lukEB, coding for a SNP within the lukE gene, and the genes sea and sed, coding for staphylococcal enterotoxins $\mathrm{A}$ and $\mathrm{D}$, respectively. The new procedure relies on a rapid isolation of the bacterial DNA from enriched milk samples using a commercial kit and the qPCR for the new target gene $a d l b$, which is highly inclusive and exclusive for Staph. aureus GTB. Additionally, the new $\mathrm{qPCR}$ assay shows a high analytical sensitivity and is characterized by an excellent diagnostic sensitivity and specificity, enabling a very reliable detection of GTBpositive cows and a clear exclusion when the test is negative. Because it analyzes a single target gene, the new analytical procedure is particularly suitable for routine application requiring high throughput.

\section{Inclusivity and Exclusivity}

The 3 adlb-negative strains were unrelated and had different origins. Two strains were obtained from clinical milk samples of subclinical IMI collected in Switzerland and 1 strain was isolated from a sample collected in Austria during the European study by Cosandey et al. (2016). One possible reason for the negativity of these 3 strains for the new target is the loss of the gene adlb. This could be the consequence of the strain conservation process, as described by van Griethuysen et al. (2005) for the loss of the mecA gene in Staph. aureus after $2 \mathrm{yr}$ of storage at $-80^{\circ} \mathrm{C}$. The only nonGTB strain being positive for adlb was Staph. aureus of genotype N. Based on our own bioinformatics analyses, this genotype was found to be genetically very close to Staph. aureus GTB (H. U. Graber, unpublished data). Compared with the qPCR assay previously developed by Boss et al. (2011), which was characterized by $100 \%$ inclusivity and exclusivity, we obtained slightly lower values. However, this may be interpreted as a negligible difference, considering the higher total number of strains selected for analysis in our study $(\mathrm{n}=161)$ versus the previous study $(\mathrm{n}=116$; Boss et al., 2011).

\section{Spiking Experiments}

Spiking experiments were carried out to investigate the influence of foreign (NSA) DNA on the qPCR signals (Ct values) of the new qPCR assay. To quantify a possible disturbance effect of foreign bacterial DNA during the detection of the target organism Staph. aureus GTB, 3 NSA strains typically found in clinical milk samples (Staph. chromogenes, Staph. sciuri, and Staph. xylosus; Taponen and Pyorala, 2009; Supré et al., 2011; Vanderhaeghen et al., 2014) were selected and individually spiked in different concentrations $\left(10^{7}\right.$ to $10^{2} \mathrm{SCE} /$ assay) in the qPCR master mix used to analyze GTB-positive samples spiked with different concentrations of the target organism $\left(10^{7}\right.$ to $10^{4} \mathrm{SCE} /$ assay). The results of our experiment confirmed that the new qPCR assay for Staph. aureus GTB is reliable also in the case of samples containing high concentrations of foreign bacterial DNA. This reflects possible field conditions of Staph. aureus GTB-positive cows additionally colonized with other typical IMI-related bacteria (e.g., other staphylococci). With a maximal range of variation of 0.58 cycles between the $\mathrm{qPCR}$ signals of samples containing only the DNA of Staph. aureus GTB and of those additionally spiked with NSA DNA, the effect of foreign DNA was minimal over the whole range of tested Staph. aureus GTB concentrations. The presence of foreign DNA in the samples never led to false-negative results for the target organism Staph. aureus GTB. This was true independent of the strain used for spiking (Staph. chromogenes, Staph. sciuri, and Staph. xylosus) and of the spiked concentration, meaning that the new qPCR assay is reliable even if the milk samples subjected to GTB analysis are highly contaminated with other staphylococcal species. According to previous studies (Boss et al., 2011; Syring et al., 2012; Voelk et al., 2014), the observed Ct differences were considerably lower than the maximal range of variation of 2 cycles, which is considered acceptable when analyzing the same sample by qPCR in duplicates. According to these results, we deduced that the presence of NSA in the milk, even in high concentrations, does not affect the stability of the new qPCR assay. This advantageous property of the new diagnostic approach makes it suitable for use as a routine test, even if cows are simultaneously infected with different mastitis pathogens.

\section{Analytical Sensitivity}

The limit of detection for the present assay was 2.35 $\times 10^{2} \mathrm{SCE} / \mathrm{mL}$, which indicates the minimal amount of 
Staph. aureus GTB to be contained in a liquid before enrichment, enabling to generate a positive qPCR result after enrichment. The observed limit of detection of the novel assay corresponds to about $34 \mathrm{cfu} / \mathrm{mL}$, considering an average conversion factor of 7 , as described by Graber et al. (2007). The analytical sensitivity of the present test is in line with that found by Boss et al. (2011) by isolating Staph. aureus GTB directly from milk. Indeed, their limits of detection were $40 \mathrm{cfu} / \mathrm{mL}$ for lukEB, $100 \mathrm{cfu} / \mathrm{mL}$ for sea, and $10 \mathrm{cfu} / \mathrm{mL}$ for sed.

\section{Repeatability}

The repeatability of the present assay seems to considerably depend on the amount of Staph. aureus GTB in the milk sample to be analyzed. In fact, both interand intra-assay experiments showed highly replicable results until $\mathrm{V}^{-4}$, which corresponded to $2.35 \times 10^{5}$ and $3.25 \times 10^{5} \mathrm{SCE} / \mathrm{mL}$ of culture before enrichment, respectively.

For concentrations $\geq 3.25 \times 10^{7} \mathrm{SCE} / \mathrm{mL}$, the resulting $\mathrm{Ct}$ values were identical, meaning that under these conditions bacterial growth ended up in a plateau (Figure 2). For a concentration of $3.25 \times 10^{6} \mathrm{SCE} /$ $\mathrm{mL}$, the mean $\mathrm{Ct}$ value was significantly higher than for the higher concentrations, but they were still very similar. A considerable Ct shift, however, was observed for $3.25 \times 10^{5} \mathrm{SCE} / \mathrm{mL}$, which also turned out to be the minimal replicable concentration.

The reasons for the high minimal bacterial concentration $\left(2.35 \times 10^{5} \mathrm{SCE} / \mathrm{mL}\right)$ required in the sample to obtain a replicable result and for the inconsistent results at lower concentrations are not completely clear. Apparently, various and probably interacting factors may influence the ability of bacteria to grow during enrichment. Based on the results of our repeatability experiments, the growth of Staph. aureus GTB in Chapman medium seems to strongly depend on having reached the critical concentration of about $10^{5} \mathrm{SCE} /$ $\mathrm{mL}$. The reason for this phenomenon remains largely unclear. What is striking is the fact that the critical concentration is the same as the one required for enterotoxin production (Paulin et al., 2011), suggesting a regulation by the quorum-sensing mechanism (Paulin et al., 2011). For a better understanding of the observed phenomenon, however, further study is required addressing the influence of various factors and mechanisms on growth of Staph. aureus GTB in culture.

\section{Diagnostic Sensitivity and Specificity (Clinical Milk Samples)}

To determine the diagnostic sensitivity and specificity of the new qPCR assay, 241 representative milk sam- ples were randomly selected from an ongoing sanitation study for Staph. aureus GTB and analyzed using both the reference qPCR assay by Boss et al. (2011) and the new $a d l b$ assay. Identical results were obtained for $93 \%$ of the samples, whereas for the remaining $7 \%$ discordant results were observed. These samples were further analyzed using the gold-standard method by Fournier et al. (2008), identifying all 16 strains as Staph. aureus GTB. Of those, 15 turned out to be GTB-positive by the adlb assay. This means that the new qPCR assay shows a higher diagnostic sensitivity than the one by Boss et al. (2011), demonstrating a relevant improvement of the GTB diagnostics. In fact, these 15 milk samples were exclusively positive for the adlb gene but negative for both enterotoxin genes sea and sed. These samples would be falsely classified as GTB-negative using the current qPCR assay by Boss et al. (2011), with the consequence that the contagious problem would persist in the herd. A further consequence is that the sanitation of whole regions would be slowed down due to new infections remaining undetected by this analytical method. With a diagnostic sensitivity of $99 \%$ and a specificity of $100 \%$, the novel assay therefore enables detection of GTB-positive and GTB-negative cows highly reliably, reducing the risk for false-negative and false-positive results in clinical milk samples to a minimum.

\section{CONCLUSIONS}

The new qPCR assay for the detection of Staph. aureus GTB in cow milk is based on the analysis of the unique target gene $a d l b$, which shows high inclusivity, exclusivity, and sensitivity at the analytical level, as well as excellent diagnostic properties. All steps of the analytical procedure (sample collection and enrichment, DNA extraction, and qPCR analysis) are straightforward and can be performed under standardized conditions. The new test can be carried out routinely, enabling laboratories to manage high numbers of milk samples. Because of these properties, the new diagnostic tool is particularly suitable for the decision-making process during sanitation programs for the contagious mastitis pathogen Staph. aureus GTB. The analysis of a unique target gene accelerates the screen of whole herds, allowing farmers and veterinarians to immediately apply preventive or control measures (segregation, therapy, culling) after the detection of infected cows, keeping the risk of new infections under control.

\section{ACKNOWLEDGMENTS}

The study was supported by a research grant of the Federal Office for Agriculture (FOAG, Berne, Swit- 
zerland), and by the Swiss National Science Foundation (SNSF, Berne, Switzerland), project number 310030_143650.

\section{REFERENCES}

Barkema, H. W., M. J. Green, A. J. Bradley, and R. N. Zadoks. 2009 Invited review: The role of contagious disease in udder health. J. Dairy Sci. 92:4717-4729.

Barkema, H. W., Y. H. Schukken, and R. N. Zadoks. 2006. Invited Review: The role of cow, pathogen, and treatment regimen in the therapeutic success of bovine Staphylococcus aureus mastitis. J. Dairy Sci. 89:1877-1895.

Boss, R., J. Naskova, A. Steiner, and H. U. Graber. 2011. Mastitis diagnostics: Quantitative PCR for Staphylococcus aureus genotype B in bulk tank milk. J. Dairy Sci. 94:128-137.

Brakstad, O. G., K. Aasbakk, and J. A. Maeland. 1992. Detection of Staphylococcus aureus by polymerase chain reaction amplification of the nuc gene. J. Clin. Microbiol. 30:1654-1660.

Bustin, S. A., V. Benes, J. A. Garson, J. Hellemans, J. Huggett, M. Kubista, R. Mueller, T. Nolan, M. W. Pfaffl, G. L. Shipley, J. Vandesompele, and C. T. Wittwer. 2009. The MIQE Guidelines: Minimum information for publication of quantitative real-time PCR experiments. Clin. Chem. 55:611-622.

Caraguel, C. G. B., H. Stryhn, N. Gagne, I. R. Dohoo, and K. L. Hammell. 2011. Selection of a cutoff value for real-time polymerase chain reaction results to fit a diagnostic purpose: analytical and epidemiologic approaches. J. Vet. Diagn. Invest. 23:2-15.

Cosandey, A., R. Boss, M. Luini, K. Artursson, M. Bardiau, F. Breitenwieser, E. Hehenberger, T. Lam, M. Mansfeld, A. Michel, G. Mosslacher, J. Naskova, S. Nelson, O. Podpecan, A. Raemy, E. Ryan, O. Salat, P. Zangerl, A. Steiner, and H. U. Graber. 2016. Staphylococcus aureus genotype B and other genotypes isolated from cow milk in European countries. J. Dairy Sci. 99:529-540.

Cremonesi, P., F. Pozzi, M. Raschetti, G. Bignoli, E. Capra, H. U. Graber, F. Vezzoli, R. Piccinini, B. Bertasi, S. Biffani, B. Castiglioni, and M. Luini. 2015. Genomic characteristics of Staphylococcus aureus strains associated with high within-herd prevalence of intramammary infections in dairy cows. J. Dairy Sci. 98:6828-6838.

Darling, A. C., B. Mau, F. R. Blattner, and N. T. Perna. 2004. Mauve: Multiple alignment of conserved genomic sequence with rearrangements. Genome Res. 14:1394-1403.

Fluit, A. C. 2012. Livestock-associated Staphylococcus aureus. Clin. Microbiol. Infect. 18:735-744

Fournier, C., P. Kuhnert, J. Frey, R. Miserez, M. Kirchhofer, T. Kaufmann, A. Steiner, and H. U. Graber. 2008. Bovine Staphylococcus aureus: association of virulence genes, genotypes and clinical outcome. Res. Vet. Sci. 85:439-448.

Fox, L. K., K. W. Bayles, and G. A. Bohach. 2001. Staphylococcus aureus mastitis. Pages 271-294 in Staphylococcus aureus Infection and Disease. A. L. Honeyman, H. Friedman, and M. Bendinelli, ed. Kluwer Academic Publishers, New York, NY.

Graber, H. U., M. G. Casey, J. Naskova, A. Steiner, and W. Schaeren. 2007. Development of a highly sensitive and specific assay to detect Staphylococcus aureus in bovine mastitic milk. J. Dairy Sci. 90:4661-4669

Graber, H. U., J. Naskova, E. Studer, T. Kaufmann, M. Kirchhofer, M. Brechbuhl, W. Schaeren, A. Steiner, and C. Fournier. 2009. Mastitis-related subtypes of bovine Staphylococcus aureus are characterized by different clinical properties. J. Dairy Sci. 92:1442-1451.

Gruet, P., P. Maincent, X. Berthelot, and V. Kaltsatos. 2001. Bovine mastitis and intramammary drug delivery: Review and perspectives. Adv. Drug Deliv. Rev. 50:245-259.

Halasa, T., M. Nielen, A. P. De Roos, R. Van Hoorne, G. de Jong, T. J. Lam, T. van Werven, and H. Hogeveen. 2009. Production loss due to new subclinical mastitis in Dutch dairy cows estimated with a test-day model. J. Dairy Sci. 92:599-606.

Heiniger, D. B. H. P. van den Borne, I. Lechner, A. Tschopp, D. Strabel, A. Steiner, and H. Meier. 2014. Cost-benefit analysis of an in- tervention to improve udder health in Swiss dairy farms. Schweiz. Arch. Tierheilkd. 156:473-481.

Hogeveen, H., K. Huijps, and T. J. Lam. 2011. Economic aspects of mastitis: New developments. N. Z. Vet. J. 59:16-23.

Hummerjohann, J., J. Naskova, A. Baumgartner, and H. U. Graber. 2014. Enterotoxin-producing Staphylococcus aureus genotype B as a major contaminant in Swiss raw milk cheese. J. Dairy Sci. 97:1305-1312.

Jensen, M. A., J. A. Webster, and N. Straus. 1993. Rapid identification of bacteria on the basis of polymerase chain reaction-amplified ribosomal DNA spacer polymorphisms. Appl. Environ. Microbiol. 59:945-952.

Kirchhofer, M., T. Kaufmann, M. Guelat-Brechbuhl, A. Michel, C. Syring, and M. Bodmer. 2011. Systematic sanitation of dairy herds with mastitis caused by Staphylococcus aureus. Schweiz. Arch. Tierheilkd. 153:361-368.

Koskinen, M. T., J. Holopainen, S. Pyorala, P. Bredbacka, A. Pitkala H. W. Barkema, R. Bexiga, J. Roberson, L. Solverod, R. Piccinini, D. Kelton, H. Lehmusto, S. Niskala, and L. Salmikivi. 2009. Analytical specificity and sensitivity of a real-time polymerase chain reaction assay for identification of bovine mastitis pathogens. J. Dairy Sci. 92:952-959.

Koskinen, M. T., G. J. Wellenberg, O. C. Sampimon, J. Holopainen, A. Rothkamp, L. Salmikivi, W. A. van Haeringen, T. J. Lam, and S. Pyorala. 2010. Field comparison of real-time polymerase chain reaction and bacterial culture for identification of bovine mastitis bacteria. J. Dairy Sci. 93:5707-5715.

Kuemmel, J., B. Stessl, M. Gonano, G. Walcher, O. Bereuter, M. Fricker, T. Grunert, M. Wagner, and M. Ehling-Schulz. 2016. Staphylococcus aureus entrance into the dairy chain: Tracking $S$. aureus from dairy cow to cheese. Front. Microbiol. 7:1603.

Landin, H., M. J. Mork, M. Larsson, and K. P. Waller. 2015. Vaccination against Staphylococcus aureus mastitis in two Swedish dairy herds. Acta Vet. Scand. 57:81.

Löffler, B., L. Tuchscherr, S. Niemann, and G. Peters. 2014. Staphylococcus aureus persistence in non-professional phagocytes. Int. J. Med. Microbiol. 304:170-176.

OIE. 2016a. 1.1.6. Principles and methods of validation of diagnostic assays for infectious diseases (NB: Version adopted in May 2013). Pages 1-16 in Manual of Diagnostic Tests and Vaccines for Terrestrial Animals 2016. Online Edition. Organisation for Animal Health (OIE), Paris, France.

OIE. 2016b. 3.6.3. Development and optimisation of nucleic acid detection assays (NB: Version adopted in May 2014). Pages 1-11 in Manual of Diagnostic Tests and Vaccines for Terrestrial Animals 2016. Online Edition. Organisation for Animal Health (OIE), Paris, France.

OIE. 2016c. 3.6.5. Statistical approaches to validation (NB: Version adopted in May 2014). Pages 1-12 in Manual of Diagnostic Tests and Vaccines for Terrestrial Animals 2016. Organisation for Animal Health (OIE), Paris, France.

Paulin, S., B. Horn, and J. A. Hudson. 2011. Factors influencing staphylococcal enterotoxin production in Dairy Products. MPI Technical. Prepared for the Ministry for Primary Industries, Wellington, New Zealand.

Petersson-Wolfe, C. S., I. K. Mullarky, and G. M. Jones. 2010. Staphylococcus aureus mastitis: Cause, detection, and control. Virginia Cooperative Extension:1-7. Accessed Jul. 18, 2017. https://www .pubs.ext.vt.edu/404/404-229/404-229.html.

Peton, V., and Y. Le Loir. 2014. Staphylococcus aureus in veterinary medicine. Infect. Genet. Evol. 21:602-615.

Pyörälä, S. 2009. Treatment of mastitis during lactation. Ir. Vet. J. 62(Suppl 4):S40-S44.

Raemy, A., M. Meylan, S. Casati, V. Gaia, B. Berchtold, R. Boss, A. Wyder, and H. U. Graber. 2013. Phenotypic and genotypic identification of streptococci and related bacteria isolated from bovine intramammary infections. Acta Vet. Scand. 55:53.

Riffon, R., K. Sayasith, H. Khalil, P. Dubreuil, M. Drolet, and J. Lagace. 2001. Development of a rapid and sensitive test for identification of major pathogens in bovine mastitis by PCR. J. Clin. Microbiol. 39:2584-2589. 
Schukken, Y. H., V. Bronzo, C. Locatelli, C. Pollera, N. Rota, A. Casula, F. Testa, L. Scaccabarozzi, R. March, D. Zalduendo, R. Guix, and P. Moroni. 2014. Efficacy of vaccination on Staphylococcus aureus and coagulase-negative staphylococci intramammary infection dynamics in 2 dairy herds. J. Dairy Sci. 97:5250-5264.

Sears, P. M., and K. K. McCarthy. 2003. Management and treatment of staphylococcal mastitis. Vet. Clin. North Am. Food Anim. Pract. 19:171-185.

Sears, P. M., B. S. Smith, P. B. English, P. S. Herer, and R. N. Gonzalez. 1990. Shedding pattern of Staphylococcus aureus from bovine intramammary infections. J. Dairy Sci. 73:2785-2789.

Sol, J., O. C. Sampimon, H. W. Barkema, and Y. H. Schukken. 2000. Factors associated with cure after therapy of clinical mastitis caused by Staphylococcus aureus. J. Dairy Sci. 83:278-284.

Sol, J., O. C. Sampimon, J. J. Snoep, and Y. H. Schukken. 1997. Factors associated with bacteriological cure during lactation after therapy for subclinical mastitis caused by Staphylococcus aureus. J. Dairy Sci. 80:2803-2808.

Sommerhäuser, J., B. Kloppert, W. Wolter, M. Zschöck, A. Sobiraj, and K. Failing. 2003. The epidemiology of Staphylococcus aureus infections from subclinical mastitis in dairy cows during a control programme. Vet. Microbiol. 96:91-102.

Studer, E., W. Schaeren, J. Naskova, H. Pfaeffli, T. Kaufmann, M. Kirchhofer, A. Steiner, and H. U. Graber. 2008. A longitudinal field study to evaluate the diagnostic properties of a quantitative real-time polymerase chain reaction-based assay to detect Staphylococcus aureus in milk. J. Dairy Sci. 91:1893-1902.

Supré, K., F. Haesebrouck, R. N. Zadoks, M. Vaneechoutte, S. Piepers, and V. S. De. 2011. Some coagulase-negative Staphylococcus species affect udder health more than others. J. Dairy Sci. 94:2329-2340.

Syring, C., R. Boss, M. Reist, M. Bodmer, J. Hummerjohann, P. Gehrig, and H. U. Graber. 2012. Bovine mastitis: The diagnostic properties of a PCR-based assay to monitor the Staphylococcus aureus genotype B status of a herd, using bulk tank milk. J. Dairy Sci 95:3674-3682

Taponen, S., and S. Pyorala. 2009. Coagulase-negative staphylococci as cause of bovine mastitis- not so different from Staphylococcus aureus? Vet. Microbiol. 134:29-36.

van den Borne, B. H., H. U. Graber, V. Voelk, C. Sartori, A. Steiner, M. C. Haerdi-Landerer, and M. Bodmer. 2017. A longitudinal study on transmission of Staphylococcus aureus genotype B in Swiss communal dairy herds. Prev. Vet. Med. 136:65-68.

van Griethuysen, A., I. van Loo, A. van Belkum, C. VandenbrouckeGrauls, W. Wannet, P. van Keulen, and J. Kluytmans. 2005. Loss of the mecA gene during storage of methicillin-resistant Staphylococcus aureus strains. J. Clin. Microbiol. 43:1361-1365.

Vanderhaeghen, W., S. Piepers, F. Leroy, C. E. Van, F. Haesebrouck, and V. S. De. 2014. Invited review: Effect, persistence, and virulence of coagulase-negative Staphylococcus species associated with ruminant udder health. J. Dairy Sci. 97:5275-5293.

Voelk, V., H. U. Graber, B. H. van den Borne, C. Sartori, A. Steiner, M. Bodmer, and M. C. Haerdi-Landerer. 2014. A longitudinal study investigating the prevalence of Staphylococcus aureus genotype B in seasonally communal dairy herds. J. Dairy Sci. 97:4184-4192.

Wyder, A. B., R. Boss, J. Naskova, T. Kaufmann, A. Steiner, and H. U. Graber. 2011. Streptococcus spp. and related bacteria: Their identification and their pathogenic potential for chronic mastitis A molecular approach. Res. Vet. Sci. 91:349-357.

Zecconi, A., and F. Scali. 2013. Staphylococcus aureus virulence factors in evasion from innate immune defenses in human and animal diseases. Immunol. Lett. 150:12-22.

Zhang, S., and G. C. Stewart. 2001. Staphylococcal enterotoxins. Pages 117-136 in Staphylococcus aureus Infection and Disease. A. L. Honeyman, H. Friedman, and M. Bendinelli, ed. Kluwer Academic Publishers, New York, NY. 